\title{
ANALISIS FAKTOR MEMENGARUHI KEPATUHAN BEROBAT LANSIA PENDERITA HIPERTENSI PADA MASA PANDEMI COVID-19 DI PUSKESMAS BULILI KOTA PALU
}

\author{
Listi Sintiadewi Dolo ${ }^{1}$, Andi Yusuf ${ }^{2}$ dan Rahmawati Azis ${ }^{3}$ \\ Program Studi Ilmu Kesehatan Masyarakat \\ Pascasarjana Sekolah Tinggi Ilmu Kesehatan Tamalatea Makassar \\ 019160069@stiktamalateamks.ac.id ${ }^{1}$,yusuf@stiktamalateamks.ac.id², \\ rahmaazis@ stiktamalateamks.ac.id ${ }^{3}$
}

\begin{abstract}
Patients with COVID-19 with comorbidities such as hypertension, heart disease, and diabetes mellitus are at great risk of causing death. The American Heart Association (AHA) noted that people with comorbid hypertension are likely to experience more severe complications if they are infected with the SARS-CoV-2 corona virus, the trigger of COVID -19. As a country with an aging population, the elderly population in Indonesia is currently estimated at 27.08 million people (10\% ) and $63.5 \%$ of health cases in the elderly with hypertension. This study aims to determine the factors that affect adherence to treatment for elderly patients with hypertension at the Bulili Health Center, Palu City. The research design used a cross sectional study. The instruments used were questionnaires, sphygmomanometer and stethoscope. The study population were all elderly people with hypertension who came for treatment at the Bulili Health Center in Palu City and a sample of 100 respondents based on the Lemeshow formula. The data obtained were processed using Univariate, Bivariate (Chi Square) and Multivariate analysis (Logistic Regression). The results of this study state that the variable that has a significant relationship is family support. Multivariate analysis showed family support variable with p-value 0.012 and OR (95\% CI) 4.0. The conclusion of this study shows that family support is the variable that most contributes 4 times to adherence to treatment for the elderly with hypertension at the Bulili Health Center, Palu City. This means that high family support has a 4 times greater effect on adherence to treatment than those who have low family support after being controlled by the variables of employment status and affordability of access.
\end{abstract}

Keywords $\quad$ : Covid-19, hypertension, medication adherence, elderly

\begin{abstract}
ABSTRAK
Penderita Covid-19 dengan penyakit penyerta seperti hipertensi, jantung serta diabetes melitus berisiko besar mengakibatkan kematian. American Heart Association (AHA) mencatat orang dengan penyakit penyerta hipertensi berpeluang mengalami komplikasi lebih parah bila mereka terinfeksi Virus Corona SARS-CoV-2, pemicu Covid-19. Sebagai negara dengan bentuk masyarakat berumur (Aging population), di mana populasi lanjut usia di Indonesia sekarang ini diperkirakan sebesar 27,08 juta jiwa atau sekitar $10 \%$ dari total masyarakat dan kasus kesehatan pada lanjut usia yang mengidap hipertensi adalah $63,5 \%$. Penelitian ini bertujuan untuk mengetahui faktor yang memengaruhi kepatuhan berobat lansia penderita hipertensi di Puskesmas Bulili Kota Palu. Desain penelitian menggunakan Cross sectional study. Instrumen yang digunakan kuesioner, tensimeter dan stetoskop. Populasi dalam penelitian ini adalah seluruh lanjut usia penderita hipertensi yang datang berobat di Puskesmas Bulili Kota Palu dengan sampel sebanyak 100 responden, berdasarkan rumus Lemeshow. Data yang diperoleh diolah dalam bentuk analisis Univariat, Bivariat (Chi Square) dan Multivariat (Regresi Logistik Berganda). Hasil penelitian ini diperoleh bahwa variabel yang memiliki hubungan yang signifikan yakni dukungan keluarga. Analisis multivariat menunjukkan variabel dukungan keluarga dengan $p$-value 0,012 $(p<0,05)$ dengan nilai OR $(95 \% \mathrm{CI})$ sebesar 4,0. Kesimpulan penelitian ini menunjukkan bahwa dukungan keluarga merupakan variabel yang paling memberikan
\end{abstract}


kontribusi 4 kali lipat terhadap kepatuhan berobat lansia penderita hipertensi di Puskesmas Bulili Kota Palu. Artinya dukungan keluarga yang tinggi memiliki pengaruh 4 kali lebih besar untuk patuh berobat dibanding mereka yang memiliki dukungan keluarga rendah setelah dikontrol oleh variabel status pekerjaan dan keterjangkauan akses.

Kata kunci $\quad$ : Covid-19, hipertensi, kepatuhan berobat, lansia

\section{PENDAHULUAN}

Pandemi covid-19 yang terjadi dimasa ini mengakibatkan terimbasnya seluruh sektor kehidupan, khususnya sektor kesehatan masyarakat. American Heart Association (AHA) mencatat, orang dengan penyakit penyerta hipertensi atau tekanan darah tinggi berpeluang mengalami komplikasi lebih parah bila mereka terinfeksi Virus Corona SARS-CoV-2, pemicu Covid-19. Data penemuan penderita Covid-19 di Indonesia menunjukkan bahwa sebagian besar penderita yang meninggal dunia mempunyai riwayat penyakit hipertensi dengan penyerta lainnya seperti penyakit jantung, ginjal, diabetes sampai stroke (Tiksnadi, 2020) dalam (Widyastuti and Nurul Istiqomah, 2021).

Pandemi ini berdampak multidimensi pada bermacam aspek kehidupan. Wanita lanjut usia khususnya serta lanjut usia pada umumnya mengalami risiko yang signifikan terserang covid-19. Informasi dari World Health Organization lebih dari $95,0 \%$ kematian terjadi di usia 60 tahun keatas serta kurang lebih $50,0 \%$ yang berumur 80 tahun. 8 dari 10 kematian tersebut dialami oleh orang yang memiliki lebih dari satu komorbid penyakit kardiovaskular, hipertensi dan diabetes serta penyakit kronis yang lain (Kementerian Pemberdayaan Perempuan dan Perlindungan Anak Republik Indonesia, 2020).

World Health Organization melaporkan, lebih dari 1 miliar orang di dunia mengidap hipertensi, 2 per 3 diantaranya ditemukan di negera berkembang yang berpendapatan kecil hingga sedang. Setiap tahun hipertensi telah menyebabkan kematian sekitar 8 juta orang, kematian 1,5 juta orang tersebut terjadi di Asia Tenggara, pada penelitian Armilawaty (2007) dalam (Nopitasari et al., 2019).

Sebagai Negara dengan bentuk masyarakat berumur (Aging population), di mana populasi lanjut usia sekarang ini diproyeksikan sebesar 27,08 juta jiwa atau 9,99\% dari total masyarakat maka kasus kesehatan pada lanjut usia di Indonesia antara lain $63,5 \%$ mengidap darah tinggi, $5,7 \%$ dengan Diabetes Mellitus, 4,5\% Penyakit Jantung, 4,4\% dengan Stroke, $0,8 \%$ dengan masalah Ginjal serta $0,4 \%$ mengidap Kanker pada Riskesdas (2018) dalam (Wasistiono Indrayani et al., 2020).

Di Indonesia, kejadian hipertensi menurut data Riskesdas tahun 2018 yang didapatkan dari pengukuran pada usia $\geq 18$ tahun sebanyak $34,11 \%$, namun yang terdeteksi oleh tenaga kesehatan atau memiliki riwayat minum obat hanya $8,36 \%$. Perihal tersebut menunjukkan bahwa permasalahan hipertensi di masyarakat belum terdiagnosis serta terjangkau oleh tenaga kesehatan.

Kepatuhan berobat ialah salah satu pendukung utama tercapainya dampak pengobatan penyembuhan darah tinggi. Ketidakpatuhan penderita darah tinggi dalam minum obat dapat meningkatkan morbiditas, mortalitas serta biaya rawat inap dan dampak pengobatan yang menyebabkan melonjaknya risiko komplikasi (Oktaviani, Zunnita and Handayani, 2020). Pengidap hipertensi yang mentaati penyembuhan dengan antihipertensi di Cina sebanyak 43,0\%, Gambia 27,0\% serta Seychelles 26,0\%. Sedangkan di negara maju seperti Amerika Serikat hanya $51,0 \%$ dari penderita rawat 
inap mentaati pengobatan (Ihwatun et al., 2020).

Informasi Nasional di Amerika menguraikan bahwa kepatuhan berobat dari masyarakat yang disurvei hanya 24,0\% responden yang benar-benar patuh; $24,0 \%$ responden sebagian besar patuh; 20,0\% dan $16,0 \%$ tidak patuh serta $15,0 \%$ sebagian besar tidak patuh pada penelitian National Community Pharmacist association (2013) dalam (Anugrah et al., 2020). Sedangkan Informasi Nasional Riskesdas membuktikan bahwa kecenderungan penyakit darah tinggi di Indonesia ditinjau dari kepatuhan minum obat antihipertensi secara teratur $54,40 \%$, tidak teratur $32,27 \%$, yang terdiri dari alasan tidak minum obat antihipertensi dengan teratur disebabkan karena sering lupa 11,5\%, obat tidak tersedia $2,0 \%$, minum obat konvensional 14,5\%, tidak sanggup membeli obat teratur $8,1 \%$, tidak teratur berobat $31,3 \%$ serta telah merasa sehat $59,8 \%$. Sebaliknya proporsi kepatuhan mengukur tekanan darah secara teratur $12,0 \%$, kadang-kadang $47,0 \%$ serta tidak teratur $41,0 \%$ (Laporan Nasional Riskesdas, 2018; Ihwatun et al., 2020; Anugrah et al., 2020). Setyoningsih \& Zaini dalam (Setyoningsih and Zaini, 2020) yang meneliti tentang disiplin dampak pengobatan pada penderita darah tinggi di poli jaga RSUD Dokter Soetrasno Rembang memaparkan bahwa penderita yang tidak patuh $34,1 \%$, taat rendah $34,1 \%$, patuh sedang $21,9 \%$ serta patuh tinggi 9,9\%. Diperoleh hasil $p$-value 0.021 ( $p \leq$ $0.05)$ dan disimpulkan bahwa ada hubungan yang bermakna antara tingkatan disiplin minum obat dengan pendapatan dampak pengobatan yang di harapkan.

Di Provinsi Sulawesi Tengah, kasus penyakit tidak menular hipertensi tahun 2015 sebanyak 96.797 kasus, 2016 sebanyak 96.213 kasus dan 2017 sebanyak 111.058 kasus. Berdasarkan data tahun 2019 persentase penduduk yang mendapatkan pelayanan kesehatan hipertensi kategori usia $\geq 15$ tahun adalah sebesar 51,2\% (Profil Dinas Kesehatan Provinsi Sulteng, 2019). Tahun 2018 kasus hipertensi menjadi trend penyakit pasca bencana dan berdasarkan laporan Dinas Kesehatan Kota Palu mulai dari 1 Oktober sampai dengan 15 Januari 2019, hipertensi termasuk dalam 10 penyakit tertinggi di Kota Palu pada penelitian Lamadjido (2018) dalam (Sagita, Budiman and Nurjanah, 2019). Data capaian Standar Pelayanan Minimal Dinas Kesehatan Kota Palu melaporkan prevalensi kasus hipertensi tahun 2020 adalah 57,0\%.

Puskesmas Bulili sebagai salah satu Puskesmas di Kota Palu yang memiliki 2 kelurahan sebagai wilayah kerjanya yakni kelurahan Birobuli Selatan dan kelurahan Petobo. Cakupan pelayanan penderita hipertensi tahun 2020 di wilayah kerja Puskesmas Bulili sebesar 41,0\% di mana masing-masing kelurahan Birobuli Selatan sebanyak 910 kasus dari target 2.025 kasus atau $45,0 \%$ dan kelurahan Petobo sebanyak 656 kasus dari target 1.838 kasus atau 36,0\%. Angka ini merupakan capaian terendah dari semua Puskesmas se-Kota Palu sehingga dianggap memenuhi kriteria untuk dilakukan penelitian tentang masalah apa saja yang menyebabkan pelayanan penderita hipertensi khususnya pada lanjut usia di wilayah kerjanya belum mencapai target yang di harapkan.

Penelitian ini menganalisis pengaruh usia, jenis kelamin, tingkat pendidikan, status pekerjaan, tingkat pengetahuan, keterjangkauan akses pelayanan kesehatan, peran petugas kesehatan serta dukungan keluarga terhadap kepatuhan berobat lanjut usia penderita hipertensi di Puskesmas Bulili Kota Palu yang dapat dijadikan bahan evaluasi terhadap rendahnya capaian Program Pencegahan dan Pengendalian Penyakit khususnya Program Penyakit Tidak Menular dan capaian Standar Pelayanan Minimal Bidang Kesehatan khususnya indikator pelayanan kesehatan penderita hipertensi. 


\section{METODE}

Penelitian menggunakan metode survei analitik dengan rancangan Cross sectional study. Populasi penelitian adalah seluruh lanjut usia penderita hipertensi yang datang berkunjung ke Puskesmas Bulili Kota Palu dan dilaksanakan sejak minggu pertama April sampai minggu ketiga Mei tahun 2021. Penetapan sampel penelitian menggunakan teknik purposive sampling sebanyak 100 responden dengan rumus Lemeshow. Pengumpulan data dilakukan melalui wawancara menggunakan kuesioner. Pengolahan data berupa coding, entri dan tabulating serta dianalisis untuk menguji hipotesis secara bivariat (Chi square) dan multivariat menggunakan Uji Regresi Logistik Berganda dengan bantuan aplikasi SPSS.

\section{HASIL}

Tabel 1. Distribusi Frekuensi berdasarkan Kepatuhan Berobat Lansia Penderita Hipertensi

\begin{tabular}{ccc} 
Kepatuhan berobat & f & \% \\
\hline Rendah & 37 & 37,0 \\
Tinggi & 63 & 63,0 \\
\hline Total & 100 & 100,0 \\
\hline
\end{tabular}

Berdasarkan tabel 1 diketahui 63 responden $(63,0 \%)$ lansia penderita hipertensi memiliki kepatuhan berobat yang tinggi.

Tabel 2. Distribusi Frekuensi berdasarkan Tingkat Pengetahuan Lansia Penderita Hipertensi

\begin{tabular}{ccc}
\hline Tingkat Pengetahuan & f & \% \\
\hline Rendah & 4 & 4,0 \\
Tinggi & 96 & 96,0 \\
\hline Total & 100 & 100,0 \\
\hline Berdasarkan & tabel & diketahui
\end{tabular}
responden $(96,0 \%)$ lansia memiliki tingkat pengetahuan yang tinggi tentang hipertensi.

Berdasarkan tabel 3 diketahui 94 responden $(94,0 \%)$ lansia penderita hipertensi dapat mengakses pelayanan kesehatan dengan terjangkau.
Tabel 3. Distribusi Frekuensi berdasarkan Keterjangkauan Akses Pelayanan Kesehatan Lansia Penderita Hipertensi

\begin{tabular}{ccc}
\hline $\begin{array}{c}\text { Keterjangkauan Akses } \\
\text { Pelayanan Kesehatan }\end{array}$ & f & \% \\
\hline Kurang Terjangkau & 6 & 6,0 \\
Terjangkau & 94 & 94,0 \\
\hline Total & 100 & 100,0 \\
\hline
\end{tabular}

Tabel 4. Distribusi Frekuensi Peran Petugas Kesehatan pada Lansia Penderita Hipertensi

\begin{tabular}{ccc}
\hline Peran Petugas Kesehatan & f & \% \\
\hline Rendah & 1 & 1,0 \\
Tinggi & 99 & 99,0 \\
\hline Total & 100 & 100,0 \\
\hline
\end{tabular}

Berdasarkan tabel 4 diketahui 99 responden $(99,0 \%)$ lansia menyatakan bahwa peran petugas tinggi terhadap pengobatan hipertensi mereka.

Tabel 5. Distribusi Frekuensi Berdasarkan Dukungan Keluarga Terhadap pada Lansia Penderita Hipertensi

\begin{tabular}{ccc}
\hline Dukungan Keluarga & f & \% \\
\hline Rendah & 25 & 25,0 \\
Tinggi & 75 & 75,0 \\
\hline Total & 100 & 100,0 \\
\hline
\end{tabular}

Berdasarkan tabel 5 diketahui 75 responden $(75,0 \%)$ lansia penderita hipertensi mendapatkan dukungan keluarga yang tinggi terhadap pengobatannya.

Tabel 6. Distribusi Frekuensi Karakteristik Lansia Penderita hipertensi

\begin{tabular}{lcc}
\hline \multicolumn{1}{c}{ Karakteristik } & f & $\%$ \\
\hline Usia & & \\
55-65 (Lansia Elderly) & 50 & 50,0 \\
66-74 (Lansia Muda) & 37 & 37,0 \\
75-90 (Lansia Tua) & 13 & 13,0 \\
\hline Jenis Kelamin & & \\
Laki-Laki & 37 & 37,0 \\
Perempuan & 63 & 63,0 \\
\hline
\end{tabular}

\begin{tabular}{lrc}
\hline Tingkat Pendidikan & & \\
SD & 25 & 25,0 \\
SMP & 24 & 24,0 \\
SMA & 36 & 36,0 \\
S1 (Sarjana) & 15 & 15,0 \\
\hline Status Pekerjaan & \multicolumn{3}{c}{17,0} \\
Bekerja & 17 & 17,0 \\
Tidak bekerja & 83 & 83,0 \\
\hline Berdasarkan tabel 6 diketahui 50 \\
responden adalah usia antara 55-65 tahun \\
lansia elderly (50,0\%) dan proporsi
\end{tabular}


responden terbanyak yaitu lansia perempuan $(63,0 \%)$, sebagian besar berpendidikan SMA $(36,0 \%)$ serta di tinjau dari segi pekerjaan proporsi responden terbanyak adalah lansia yang tidak bekerja $(83,0 \%)$.

Tabel 7. Pengaruh Dukungan Keluarga dengan Kepatuhan Berobat Lansia Penderita Hipertensi

\begin{tabular}{|c|c|c|c|c|c|c|c|c|}
\hline \multirow{3}{*}{$\begin{array}{l}\text { Dukungan } \\
\text { Keluarga }\end{array}$} & \multicolumn{4}{|c|}{ Kepatuhan Berobat Hipertensi } & \multicolumn{4}{|c|}{ OR } \\
\hline & \multicolumn{2}{|c|}{ Rendah } & \multicolumn{2}{|c|}{ Tinggi } & \multicolumn{2}{|c|}{ Total } & \multirow{2}{*}{$(95 \% C I)$} & \multirow{2}{*}{$\begin{array}{c}P \\
\text { value }\end{array}$} \\
\hline & $\mathrm{f}$ & $\%$ & $\mathrm{f}$ & $\%$ & $\Sigma$ & $\%$ & & \\
\hline Rendah & 18 & 18,0 & 7 & 7,0 & 25 & 25,0 & $\begin{array}{c}3,6 \\
(1,2-10,8)\end{array}$ & 0,018 \\
\hline Tinggi & 19 & 19,0 & 56 & 56,0 & 75 & 75,0 & & \\
\hline
\end{tabular}

Berdasarkan tabel 7 diketahui dukungan keluarga yang tinggi $(75,0 \%)$ akan mendorong kepatuhan berobat yang tinggi pada lansia penderita hipertensi yakni $56,0 \%$. Hasil uji statistik menunjukkan $p$ value variabel dukungan keluarga sebesar $0,018(p<0,05)$ yang artinya terdapat pengaruh yang bermakna antara dukungan keluarga dengan kepatuhan berobat lansia penderita hipertensi, di mana nilai Odd Ratio 3,6 yang artinya lansia yang mendapat dukungan keluarga yang tinggi memberikan pengaruh 3,6 kali lebih patuh berobat dibanding lansia yang memiliki dukungan keluarga yang rendah.

Tabel 8. Pengaruh Kepatuhan Berobat Lansia Penderita Hipertensi dengan Variabel Perancu

\begin{tabular}{|c|c|c|c|c|c|c|c|}
\hline \multirow{3}{*}{ Variabel } & \multicolumn{4}{|c|}{ Kepatuhan Berobat Hipertensi } & \multirow{2}{*}{\multicolumn{2}{|c|}{ Total }} & \multirow[t]{3}{*}{$\overline{p \text {-value }}$} \\
\hline & \multicolumn{2}{|c|}{ Rendah } & \multicolumn{2}{|c|}{ Tinggi } & & & \\
\hline & $\mathrm{f}$ & $\%$ & $\mathrm{f}$ & $\%$ & $\Sigma$ & $\%$ & \\
\hline \multicolumn{8}{|l|}{ Usia } \\
\hline 55-65 (Lansia Elderly) & 18 & 18,0 & 32 & 32,0 & 50 & 50,0 & 0,597 \\
\hline 66-74 (Lansia Muda) & 12 & 12,0 & 25 & 25,0 & 37 & 37,0 & \\
\hline 75-90 (Lansia Tua) & 7 & 7,0 & 6 & 6,0 & 13 & 13,0 & \\
\hline \multicolumn{8}{|l|}{ Jenis kelamin } \\
\hline Laki-Laki & 16 & 16,0 & 21 & 21,0 & 37 & 37,0 & 0,622 \\
\hline Perempuan & 21 & 21,0 & 42 & 42,0 & 63 & 63,0 & \\
\hline \multicolumn{8}{|l|}{ Tingkat pendidikan } \\
\hline SD & 11 & 11,0 & 14 & 14,0 & 25 & 25,0 & 0,576 \\
\hline SMP & 13 & 13,0 & 11 & 11,0 & 24 & 24,0 & \\
\hline SMA & 5 & 5,0 & 31 & 31,0 & 36 & 36,0 & \\
\hline $\mathrm{S} 1$ (sarjana) & 8 & 8,0 & 7 & 7,0 & 15 & 15,0 & \\
\hline \multicolumn{8}{|l|}{ Status pekerjaan } \\
\hline Tidak Bekerja & 32 & 32,0 & 51 & 51,0 & 83 & 83,0 & 0,117 \\
\hline Bekerja & 5 & 5,0 & 12 & 12,0 & 17 & 17,0 & \\
\hline \multicolumn{8}{|l|}{ Tingkat pengetahuan } \\
\hline Rendah & 2 & 2,0 & 2 & 2,0 & 4 & 4,0 & 0,999 \\
\hline Tinggi & 35 & 35,0 & 61 & 61,0 & 96 & 96,0 & \\
\hline \multicolumn{8}{|l|}{ Keterjangkauan akses } \\
\hline Kurang Terjangkau & 1 & 1,0 & 5 & 5,0 & 6 & 6,0 & 0,207 \\
\hline
\end{tabular}




\begin{tabular}{|c|c|c|c|c|c|c|c|}
\hline \multirow{4}{*}{ Variabel } & \multicolumn{4}{|c|}{ Kepatuhan Berobat Hipertensi } & \multirow{3}{*}{\multicolumn{2}{|c|}{ Total }} & \multirow[t]{4}{*}{$p$-value } \\
\hline & & & & & & & \\
\hline & \multicolumn{2}{|c|}{ Rendah } & \multicolumn{2}{|c|}{ Tinggi } & & & \\
\hline & $\mathrm{f}$ & $\%$ & $\mathrm{f}$ & $\%$ & $\Sigma$ & $\%$ & \\
\hline Terjangkau & 36 & 36,0 & 58 & 58,0 & 94 & 94,0 & \\
\hline \multicolumn{8}{|l|}{ Peran petugas } \\
\hline Rendah & 1 & 1,0 & 0 & 0 & 1 & 1,0 & 1,000 \\
\hline Tinggi & 36 & 36,0 & 63 & 63,0 & 99 & 99,0 & \\
\hline
\end{tabular}

Hasil analisis hubungan kepatuhan berobat lansia penderita hipertensi dengan variabel perancu, dijelaskan sebagai berikut:

\section{Pengaruh usia dengan kepatuhan berobat}

Pada kelompok usia 55-65 tahun (lansia elderly) sebanyak 50,0\% di mana yang memiliki kepatuhan berobat tinggi ada $32,0 \%$. Hasil uji statistik menunjukkan $p$-value untuk variabel usia sebesar 0,597 $(p>0,05)$ yang artinya tidak terdapat pengaruh yang bermakna antara usia lansia dengan kepatuhan berobat hipertensi.

\section{Pengaruh jenis kelamin dengan kepatuhan berobat}

Lansia berjenis kelamin perempuan sebanyak $63,0 \%$ di mana $42,0 \%$ adalah lanjut usia dengan kepatuhan berobat tinggi. Hasil uji statistik menunjukkan nilai $p$-value untuk variabel jenis kelamin sebesar 0,622 $(p>0,05)$ yang artinya tidak adanya pengaruh yang signifikan antara jenis kelamin dengan kepatuhan berobat lanjut usia penderita hipertensi di Puskesmas Bulili Kota Palu.

\section{Pengaruh tingkat pendidikan dengan kepatuhan berobat}

Diketahui bahwa tingkat pendidikan yang paling dominan adalah SMA yakni $36,0 \%$ di mana $31,0 \%$ lanjut usia dengan kepatuhan berobat yang tinggi. Hasil uji statistik diperoleh $p$-value variabel tingkat pendidikan sebesar 0,576 $(p>0,05)$ yang artinya tidak ada pengaruh yang signifikan antara tingkat pendidikan dengan kepatuhan berobat lansia.

\section{Pengaruh status pekerjaan dengan kepatuhan berobat}

Diketahui bahwa lanjut usia yang tidak bekerja menempati urutan terbanyak yaitu $83,0 \%$ di mana 51,0\% merupakan lansia dengan kepatuhan berobat tinggi. Hasil uji statistik melaporkan $p$-value sebesar 0,117 $(p>0,05)$ yang artinya tidak terdapat pengaruh yang bermakna antara status pekerjaan dengan kepatuhan berobat.

\section{Pengaruh tingkat pengetahuan dengan kepatuhan berobat}

Tingkat pengetahuan lanjut usia mayoritas sudah tinggi $(96,0 \%)$, di mana $61,0 \%$ merupakan lanjut usia dengan kepatuhan berobat tinggi. Hasil uji statistik diperoleh $p$-value variabel tingkat pengetahuan sebesar $0,999(p>0,05)$ yang artinya tidak adanya pengaruh yang signifikan antara tingkat pengetahuan tentang hipertensi dengan kepatuhan berobat lanjut usia penyandang darah tinggi.

\section{Pengaruh keterjangkauan akses pelayanan kesehatan dengan kepatuhan berobat}

Lansia yang memiliki akses terjangkau adalah sebanyak $94,0 \%$ di mana $58,0 \%$ merupakan lansia dengan kepatuhan berobat tinggi. Hasil uji statistik menunjukkan $p$-value keterjangkauan akses pelayanan kesehatan sebesar 0,207 $(p>0,05)$ yang artinya tidak terdapat pengaruh yang signifikan antara 
keterjangkauan akses pelayanan kesehatan dengan kepatuhan berobat.

\section{Pengaruh peran petugas kesehatan dengan kepatuhan berobat}

Diketahui bahwa 99,0\% merupakan peran petugas yang tinggi di mana $63,0 \%$ lansia dengan kepatuhan berobat tinggi. Hasil uji statistik diperoleh $p$-value untuk variabel peran petugas sebesar $1,000(\mathrm{p}>$ 0,05 ) yang artinya tidak adanya pengaruh yang signifikan antara peran petugas kesehatan dengan kepatuhan berobat pada lanjut usia.

\section{Analisis Multivariat}

\begin{tabular}{lc}
\multicolumn{3}{l}{$\begin{array}{l}\text { Seleksi Variabel Kandidat Multivariat } \\
\text { Tabel } \begin{array}{c}\text { 9. Seleksi } \\
\text { Multivariat }\end{array}\end{array}$} & Variabel & Kandidat \\
\hline \multicolumn{1}{c}{ Variabel } & p-value \\
\hline Dukungan Keluarga & $\mathbf{0 , 0 1 8}$ \\
Usia & 0,597 \\
Jenis Kelamin & 0,622 \\
Tingkat Pendidikan & 0,576 \\
Status Pekerjaan & $\mathbf{0 , 1 1 7}$ \\
Tingkat Pengetahuan & 0,999 \\
Keterjangkauan Akses & $\mathbf{0 , 2 0 7}$ \\
Peran Petugas & 1,000 \\
\hline
\end{tabular}

Berdasarkan Tabel 9 diketahui variabel hasil seleksi yakni dukungan keluarga, status pekerjaan dan keterjangkauan akses diperoleh $p$-value $<0,25$ dan variabel tersebut akan masuk ke dalam analisa multivariat untuk dilakukan Uji Interaksi dan Uji Counfounding. Sementara itu variabel usia, jenis kelamin, tingkat pendidikan, tingkat pengetahuan serta peran petugas tidak diikutsertakan dalam analisa multivariat sebab memiliki $p$-value $>0,25$.

Tabel 10. Pemodelan Multivariat

\begin{tabular}{lcc}
\hline \multicolumn{1}{c}{ Variabel } & $\boldsymbol{p}$-value & OR $\mathbf{( 9 5 \%} \boldsymbol{C I})$ \\
\hline Dukungan keluarga & 0,010 & 4,480 \\
& & $(1,4-13,9)$ \\
Status pekerjaan & 0,069 & 3,204 \\
& & $(0,9-11,2)$ \\
\hline
\end{tabular}

\begin{tabular}{|c|c|c|}
\hline $\begin{array}{l}\text { Keterjangkauan } \\
\text { akses }\end{array}$ & 0,137 & $\begin{array}{c}0,242 \\
(0,0-1,5)\end{array}$ \\
\hline
\end{tabular}
variabel yang memiliki $p$-value terbesar adalah keterjangkauan akses dengan $p$ value 0,137 yang artinya $p>0,05$ sehingga variabel keterjangkauan akses tersebut harus dikeluarkan dari model. Hasil analisis multivariat setelah variabel keterjangkauan akses dikeluarkan dari model adalah sebagai berikut (tabel 11):

Tabel 11. Hasil Multivariat Model Akhir Setelah Variabel Keterjangkauan Akses Di Keluarkan

\begin{tabular}{lcc}
\hline \multicolumn{1}{c}{ Variabel } & p-value & $\begin{array}{c}\boldsymbol{O R} \\
(\mathbf{9 5 \%} \boldsymbol{C I})\end{array}$ \\
\hline Dukungan Keluarga & 0,012 & 4,070 \\
& & $(1,3-12,1)$ \\
Status Pekerjaan & 0,074 & 3,063 \\
& & $(0,8-10,4)$ \\
\hline
\end{tabular}

Berdasarkan Tabel 11 setelah dilakukan analisis multivariat dengan melakukan uji interaksi antara variabel independen utama (dukungan keluarga) dengan variabel perancu (status pekerjaan dan keterjangkauan akses) terhadap kepatuhan berobat lansia pengidap hipertensi serta uji counfounding maka diperoleh model akhir yang dapat menjelaskan bahwa variabel dukungan keluarga memiliki p-value terbesar dibanding dengan variabel status pekerjaan $(0,012<0,05)$ sehingga dapat disimpulkan bahwa variabel dukungan keluarga yang paling berpengaruh terhadap kepatuhan berobat lansia penderita hipertensi. Diketahui pula bahwa variabel dukungan keluarga memiliki nilai Odd Ratio 4,0 yang artinya dukungan keluarga yang tinggi memiliki pengaruh 4 kali lebih besar untuk patuh berobat dibanding lanjut usia penyandang hipertensi yang memiliki dukungan keluarga rendah setelah di kontrol oleh variabel status pekerjaan dan keterjangkauan akses. 


\section{PEMBAHASAN}

\section{Pengaruh usia dengan kepatuhan berobat}

Lanjut usia merupakan istilah akhir dari proses penuaan yaitu suatu keadaan di mana seseorang akan mengalami kemunduran fisik, minat dan mental secara perlahan sehingga tidak lagi dapat melakukan tugasnya sehari-hari. UndangUndang RI No.13 tahun 1998 menyebutkan bahwa lanjut usia adalah seseorang yang usianya mencapai 60 tahun atau lebih (Rahman, 2021). Literasi kesehatan bisa menyusut bersamaan dengan bertambahnya umur. Kondisi ini disebabkan oleh penyusutan keahlian berasumsi, rentang durasi yang lama semenjak pembelajaran terakhir serta penyusutan keahlian sensoris dan bisa memengaruhi keahlian dalam membaca serta menguasai data, penelitian Omariba dan Shah et al (2010) dalam Fauzia (2018). Beberapa teori berpendapat ternyata IQ seseorang akan menurun cukup cepat sejalan dengan bertambahnya usia (Tri Retno Widianingrum, 2017). Dari 100 responden lansia penderita hipertensi yang datang berobat di Puskesmas Bulili Kota Palu selama masa Pandemi Covid-19 diperoleh 50 responden $(50,0 \%)$ adalah lansia kategori usia antara 55-65 tahun (lansia elderly) dengan kepatuhan berobat tinggi 63,0\% dan kepatuhan rendah 37,0\%. Berdasarkan hasil analisis statistik bivariat menunjukkan bahwa usia tidak berpengaruh terhadap kepatuhan lansia berobat hipertensi. Hal ini sejalan dengan teori tentang penentu perubahan perilaku penderita hipertensi pada sarana kesehatan tingkat pertama yang diteliti oleh Iche A. Liberty (2018) dalam (Liberty et al., 2018) yang menemukan bahwa determinan usia tidak berpengaruh secara signifikan.

\section{Pengaruh jenis kelamin dengan kepatuhan berobat}

Gender memperlihatkan perbandingan laki-laki dan perempuan dengan cara biologis tetapi sesungguhnya yang berperan selaku determinan Health Literacy merupakan karakter, kedudukan, tanggung jawab serta ciri antara laki-laki dan perempuan yang dibentuk dengan cara sosial, Regitz et al (2012) dalam (Fauzia, 2018). Buvinic et al (2006) mengemukakan faktor-faktor yang memengaruhi perbedaan jenis kelamin dalam perihal risiko kesehatan ialah perbandingan biologis serta fisiologis antara laki-laki dan perempuan, perbedaan umur harapan hidup, perbandingan akses perempuan dalam mendapatkan metode proteksi sosial (asuransi kesehatan serta sosial), norma adat, keyakinan religius, serta ketentuan keluarga dan sikap yang memastikan peranperan dan posisi laki-laki serta perempuan dalam masyarakat, perbedaan jenis kelamin dalam pendidikan, perbedaan pendapat, serta Interaksi antara etnis serta gender.

Dari 100 responden lansia hipertensi yang datang berobat di Puskesmas Bulili Kota Palu selama masa Pandemi Covid-19 diperoleh proporsi responden terbanyak yaitu lansia perempuan $(63,0 \%)$. Hasil uji statistik menunjukkan jenis kelamin tidak memberikan pengaruh terhadap kepatuhan berobat lanjut usia penderita hipertensi di Puskesmas Bulili Kota Palu. Hal ini berlawanan dengan hasil riset yang dilakukan oleh Alphonce (2012) yang membuktikan bahwa kategori jenis kelamin mempunyai hubungan yang bermakna dengan tingkat kepatuhan berobat hipertensi (p 0,044) dalam (Listiana et al., 2020).

\section{Pengaruh tingkat pendidikan dengan kepatuhan berobat}

Secara langsung pendidikan memengaruhi keahlian seorang dalam memahami bermacam aspek serta mengakumulasi dan menafsirkan bermacam data termasuk data yang berhubungan dengan kesehatan. Kemampuan ini pada kesimpulannya akan memengaruhi preferensi seorang dan memilih sikap serta gaya hidupnya. Tidak hanya berakibat pada wawasan kesehatan, 
pendidikan juga melahirkan kompetensi yang diperlukan untuk pendidikan kesehatan misalnya keahlian membaca informasi kesehatan atau keahlian memakai internet. Dengan cara tidak langsung, pendidikan juga bisa memengaruhi pekerjaan dan pendapatan seorang yang pada kesimpulannya memengaruhi tingkatan Health Literacy, Canadian Council of Learning (2008) dalam (Fauzia, 2018). Teori Lawrence Green mengemukakan bahwa kesehatan individu atau masyarakat dipengaruhi oleh salah satu faktor utama yakni perilaku (behavior causes) yang terbentuk dari faktor predisposisi (predisposing factor) yaitu pendidikan atau pengetahuan.

Berdasarkan hasil analisis Univariat dari 100 responden lansia penderita hipertensi yang datang berobat ke Puskesmas Bulili Kota Palu di peroleh sebagian besar lanjut usia berpendidikan SMA $(36,0 \%)$, di mana hasil Uji Statistik Bivariat menunjukkan tidak adanya pengaruh signifikan antara tingkat pendidikan dengan kepatuhan berobat lansia penderita hipertensi. Hal ini sejalan dengan hasil penelitian Iche A Liberty (2018) dalam (Liberty et al., 2018) mengemukakan bahwa tingkat pendidikan tidak berpengaruh terhadap kepatuhan pasien berobat hipertensi dalam mengkonsumsi obat. Jika disandingkan dengan pendapat Lawrence Green yang mengatakan bahwa pendidikan merupakan salah satu faktor penentu perubahan perilaku kesehatan individu dan masyarakat, maka hal tersebut tidak selamanya benar karena informasi tentang kesehatan tidak harus diperoleh melalui pendidikan formal tetapi juga informal. Hasil penelitian di Puskesmas Bulili Kota Palu dapat menjelaskan bahwa informasi kesehatan dan perilaku kepatuhan berobat lanjut usia penderita hipertensi tidak dipengaruhi oleh tingkat pendidikan formal lanjut usia tetapi bisa didapatkan dari sumber lain seperti media massa, audio visual, kelompok atau organisasi lanjut usia, Health Education oleh tenaga kesehatan, informasi dari orang terdekat atau keluarga dan lain sebagainya.

\section{Pengaruh status pekerjaan dengan kepatuhan berobat}

Teori Thomas yang dikutip oleh Nursalam (2003) mendefinisikan bahwa sesuatu yang harus dilakukan terutama untuk menunjang kehidupan seseorang dan keluarganya disebut pekerjaan. Kondisi kemunduran fisik, minat dan mental lanjut usia secara perlahan mengakibatkan mereka tidak lagi dapat melakukan tugasnya seharihari apalagi bekerja.

Lansia hipertensi yang datang berobat ke Puskesmas Bulili Kota Palu selama masa Pandemi Covid-19 diperoleh proporsi lansia yang tidak bekerja sebanyak 83,0\% dan hasil Uji Bivariat diperoleh tidak adanya pengaruh yang signifikan antara status pekerjaan dengan kepatuhan berobat lansia penyandang hipertensi. Sedangkan hasil analisis Multivariat menunjukkan nilai Odd Ratio 2,6 yang berarti lanjut usia yang tidak bekerja memberikan pengaruh 2,6 kali lebih patuh berobat hipertensi dibanding lansia yang bekerja.

Penelitian ini sejalan dengan Listiana (2020) dalam penelitiannya menemukan hasil Uji Statistik Chi-Square (Pearson Chi-Square) diperoleh nilai $\chi 2=9,401$ dengan $\mathrm{p}=0,009<\alpha 0,05$ yang berarti bermakna dan Ho ditolak sehingga dapat disimpulkan terdapat hubungan yang signifikan antara status pekerjaan dengan kepatuhan penderita hipertensi. Hasil riset Su-Jin Cho (2014) juga membuktikan bahwa pekerjaan memiliki kemaknaan terhadap kepatuhan berobat penderita hipertensi ( $p$-value 0,006) di mana penderita yang tidak bekerja potensial lebih patuh terhadap pengobatan dibanding yang bekerja.

Berdasarkan Teori perilaku L. Green yang mengemukakan bahwa pekerjaan merupakan salah satu faktor predisposisi yang memengaruhi kesehatan individu atau lanjut usia maka hal tersebut berbanding 
lurus dengan teori Thomas yang dikutip dalam Nursalam (2003) yang mengatakan seorang yang bekerja akan memiliki waktu terbatas berkunjung ke sarana pelayanan kesehatan sehingga akan memengaruhi kepatuhan berobatnya.

\section{Pengaruh tingkat pengetahuan dengan kepatuhan berobat}

Hasil dari tahu serta pengindraan terhadap objek tertentu melalui panca indra manusia yakni penglihatan, pendengaran, penciuman, rasa dan raba disebut pengetahuan. Sebagian besar pengetahuan manusia diperoleh melalui mata dan telinga. Tanpa pengetahuan, seseorang tidak mempunyai dasar untuk menentukan tindakan dan mengambil keputusan terhadap masalah yang dihadapi (Adventus et al., 2016; Ziyana Walidah, 2017).

Lansia hipertensi yang datang berobat ke Puskesmas Bulili Kota Palu selama masa Pandemi Covid-19 diperoleh proporsi tingkat pengetahuan yang tinggi sebanyak 96,0\% dan hasil uji bivariat diperoleh tidak adanya pengaruh yang signifikan antara tingkat pengetahuan dengan kepatuhan berobat. Hasil penelitian tersebut kontradiksi dengan penelitian Hanum (2019), Diliantry (2019), Yulike Mangendai (2017), Pratiwi (2017), Candrayani (2020) dan Winny (2018) yang menemukan bahwa terdapat hubungan yang signifikan antara pengetahuan dengan kepatuhan pasien dalam minum obat antihipertensi.

\section{Pengaruh keterjangkauan akses pelayanan kesehatan dengan kepatuhan berobat}

Depkes RI (2013) dalam (Nuvri Nur Ardiyantika, 2019) menyatakan bahwa salah satu alasan untuk tidak bertindak serta berusaha mengambil sikap dalam menghadapi kondisi sakit adalah karena fasilitas kesehatan yang jauh jaraknya atau tidak terjangkaunya akses pelayanan kesehatan. Keterjangkauan akses yang dimaksud dalam riset ini adalah pengamatan dari aspek jarak, waktu tempuh, situasi jalan serta kemudahan transportasi dalam mengakses pelayanan kesehatan.

Hasil analisis Statistik didapatkan responden di Puskesmas Bulili Kota Palu proporsi lansia dengan akses yang terjangkau $95,0 \%$ dan tidak terdapat pengaruh antara keterjangkauan akses pelayanan kesehatan dengan kepatuhan berobat lanjut usia penyandang hipertensi sedangkan hasil uji multivariat diperoleh nilai Odd Ratio 0,3 yang artinya akses pelayanan kesehatan yang terjangkau pada lansia penderita hipertensi akan memberikan pengaruh 0,3 kali lebih patuh berobat dibandingkan akses pelayanan lansia yang kurang terjangkau.

Hasil penelitian ini berbanding lurus dengan riset yang dilakukan oleh Nuvri (2019) di mana diketahui terdapat hubungan yang bermakna antara akses pelayanan kesehatan yang terjangkau dengan disiplin pengobatan pasien hipertensi di Posbindu PTM Desa Sidorejo Kecamatan Geneng Kabupaten Ngawi yang dibuktikan oleh hasil Uji Chi-square $p$ value sig $0,033<\alpha 0,05$ dan nilai $\mathrm{RP}$ sebesar 5,625 yang artinya penderita dengan kemudahan akses kepelayanan kesehatan memiliki 5,6 kali peluang lebih patuh dalam pengobatan rutin.

Di sisi lain, ada beberapa hasil penelitian yang berbanding terbalik atau bertentangan dengan hasil di atas. Rosaria dan Meliyana (2017) dalam (R. I. Pratiwi, 2017) menemukan $p$-value $0,588(\mathrm{p}>0,05)$ yang artinya tidak terdapat pengaruh antara keterjangkauan akses pelayanan kesehatan dengan disiplin penderita dalam pengobatan.

\section{Pengaruh peran petugas kesehatan dengan kepatuhan berobat}

Faktor yang berhubungan dengan teori perilaku L.Green menurut Notoatmodjo (2010) dalam (Nuvri Nur Ardiyantika, 2019) antara lain adalah terdapatnya aspek yang menguatkan ataupun mendorong yaitu 
tindakan atau sikap aparat kesehatan yang mensupport penderita untuk disiplin dalam berobat. Kedudukan tenaga kesehatan merupakan aspek pendorong yang bisa mengubah sikap kesehatan seseorang. Aparat kesehatan yang lebih ramah akan memberi akibat positif bagi penderita. Tidak hanya itu, kedudukan aparat kesehatan dalam pelayanan kesehatan berperan sebagai donator rasa aman (comforter) ataupun penjaga (protector) serta pemelihara dan rehabilitator.

Diketahui hasil Uji Statistik Chi-Square diperoleh proporsi peran petugas yang tinggi sebanyak $99,0 \%$ dan hasil Uji Bivariat menunjukkan tidak adanya pengaruh yang signifikan antara peran petugas kesehatan dengan kepatuhan berobat lanjut usia penyandang hipertensi di Puskesmas Bulili Kota Palu. Hal ini sejalan dengan penelitian sebelumnya oleh Nuvri Nur Ardiyantika (2019) di mana hasil riset pada Uji Chi-Square diperoleh $p$-value sig $1,000>\alpha 0,05$ yang berarti tidak ada hubungan kemaknaan antara peran petugas dengan kepatuhan berobat penderita hipertensi di Posbindu PTM Desa Sidorejo Kecamatan Geneng Kabupaten Ngawi.

Bertentangan dengan hasil penelitian yang dilakukan oleh Exa Puspita, Eka Oktaviarini dan Yunita Dyah Puspita Santik (2017) dalam (Puspita et al., 2017) diperoleh hasil bahwa variabel peran petugas kesehatan dengan nilai $\mathrm{p}<0,05$ (95\% CI $=2,172-5,391)$ memiliki hubungan yang bermakna terhadap kepatuhan penderita hipertensi dalam menjalani pengobatan. Sejalan dengan hasil Riset Rosaria dan Meliyana (2017) dalam (R. I. Pratiwi, 2017) diperoleh p-value 0,000 yang juga membuktikan terdapat hubungan antara peran petugas kesehatan dengan disiplin minum obat pasien hipertensi.

\section{Pengaruh dukungan keluarga dengan kepatuhan berobat}

Menurut Notoatmodjo (2010) Keluarga adalah komponen terkecil masyarakat.
Untuk mencapai sikap sehat masyarakat harus diawali pada masing-masing aturan keluarga. Dalam teori pembelajaran dikatakan bahwa keluarga merupakan tempat persemaian manusia selaku warga masyarakat sehingga apabila persemaian itu kurang baik maka akan memengaruhi kehidupan masyarakat. Promosi kesehatan sangat berperan penting agar setiap keluarga menjadi tempat yang mendukung peningkatan sikap sehat untuk generasi muda selaku warga masyarakat.

Berdasarkan hasil Uji Statistik pada 100 responden lansia hipertensi di Puskesmas Bulili Kota Palu diperoleh $p$ value dukungan keluarga sebesar 0,018 yang artinya terdapat pengaruh yang bermakna antara dukungan keluarga dengan kepatuhan berobat lansia penderita hipertensi, di mana nilai Odd Ratio pada hasil analisis model akhir Multivariat adalah 4,0 yang memberikan arti bahwa dukungan keluarga yang tinggi pada lanjut usia pengidap hipertensi memiliki peluang 4 kali lebih besar untuk patuh berobat dibanding lansia yang memiliki dukungan keluarga rendah setelah dikontrol oleh variabel status pekerjaan dan keterjangkauan akses pelayanan kesehatan. Keluarga sangat berperan dalam mendampingi lansia dalam perawatan di rumah, diet rendah garam, kontrol tekanan darah, ketepatan waktu minum obat, janji temu untuk kontrol ke dokter dan rutin menjalani pengobatan hipertensinya. Pada penelitian Masriadi et al., (2018) menggunakan uji wilcoxon, diperoleh hasil bahwa terdapat perbedaan tekanan darah sistolik sebelum dan sesudah pengobatan dengan mengubah gaya hidup dengan mengatur pola makan seperti mengurangi asupan garam, konsumsi kopi (kafein) dan kelola stres dengan memperbanyak aktivitas. Hipertensi membutuhkan penyembuhan yang lama sehingga dukungan sosial dibutuhkan dalam pengobatannya. Dukungan keluarga ialah tindakan, sikap serta penerimaan terhadap penderita yang sakit. Dorongan keluarga 
serta sahabat bisa menolong seorang dalam melaksanakan program-program kesehatan serta secara umum orang yang mendapatkan perhatian, kepedulian serta bantuan yang mereka butuhkan dari orang lain akan lebih mudah menerima nasehat kedokteran, Puspita (2016) dalam (Nuvri Nur Ardiyantika, 2019).

Pada penelitian (Masriadi, Arifin and Azis, 2019), menyatakan bahwa dengan adanya pengawasan minum obat (Supervisory Drink Drugs/SDG) dari anggota keluarga yang bertujuan untuk mengawasi dan memastikan pasien dalam terapi pengobatan anti hipertensi, dapat memengaruhi penurunan tekanan darah sistolik dan diastolik. Pada pasien hipertensi dengan intervensi (SDG) pada kelompok eksperimen selama 4 minggu sangat berpengaruh terhadap penurunan tekanan darah, hal ini dikarenakan pasien mampu mengatur diri sendiri untuk patuh rutin minum obat sesuai anjuran dan menjaga tekanan darah.

Beberapa hasil penelitian yang menunjukan kesimpulan yang sama dengan hasil penelitian ini adalah Naelal (2020) dan Yulike Mangendai (2017) yang menyatakan terdapat hubungan yang signifikan antara dukungan keluarga dengan kepatuhan berobat pasien hipertensi di Puskesmas Pamarican Kabupaten Ciamis dan Puskesmas Ranotana Weru. Sebaliknya hasil riset yang kontradiksi dengan penelitian ini adalah oleh Pratiwi (2020), Hanum (2019) dan Kurnia (2016) yang menyatakan dukungan keluarga tidak memiliki keterkaitan dengan kepatuhan lanjut usia dalam menjalani pengobatan hipertensi.

\section{KESIMPULAN}

Dukungan keluarga merupakan variabel yang paling memberikan kontribusi 4 kali lipat terhadap kepatuhan berobat lansia penderita hipertensi di Puskesmas Bulili Kota Palu. Lanjut usia dengan penyakit hipertensi merupakan kelompok usia rentan terhadap pajanan infeksi penyakit menular khususnya Covid19. Tindakan pencegahan dan mitigasi penularan penyakit diperlukan dari pendampingan keluarga terhadap lansia. Keluarga berperan penting dalam mendampingi perawatan di rumah, diet rendah garam, kontrol tekanan darah, ketepatan waktu minum obat, janji temu untuk kontrol ke dokter dan rutin menjalani pengobatan hipertensinya. Bahkan sampai kepada penerapan protokol kesehatan, keluarga sebagai orang terdekat berperan mengingatkan lansia untuk tidak lupa memakai masker jika hendak berpergian, menjaga jarak minimal 1 meter dari orang yang bergejala pernapasan serta menghindari kerumunan atau keramaian.

Rendahnya cakupan pelayanan kesehatan penderita hipertensi pada masa Pandemi Covid-19 di Puskesmas Bulili Kota Palu salah satunya dapat diakibatkan karena belum maksimalnya dukungan keluarga kepada lanjut usia. Persentase lansia dengan dukungan keluarga tinggi yang berkontribusi terhadap kepatuhan berobat yang tinggi sebanyak $56,0 \%$ ini, dapat memberikan gambaran bahwa hanya setengah dari jumlah responden yang diteliti mendapatkan dukungan yang tinggi atau baik dari keluarganya.

Hal tersebut kemungkinan dapat diakibatkan karena ada beberapa lansia yang tinggal sendirian, situasi anak yang bekerja sehingga harus meninggalkan lansia dirumah beberapa saat atau lansia hidup sebatang kara (tidak punya keluarga). Penyebab klasik lainnya adalah karena beberapa lansia berasumsi bahwa pergi ke Puskesmas atau sarana pelayana kesehatan akan meningkatkan risiko mereka tertular Covid-19 sehingga mereka lebih memilih membeli alat tensimeter pribadi dan membeli obat antihipertensi di Apotek. Sehingga untuk mengatasi hal tersebut diharapkan petugas kesehatan yang ada di Puskesms Bulili Kota Palu dapat lebih meningkatkan pelayanan dan pemberian informasi kesehatan kepada lansia di 
wilayah kerjanya dengan memanfaatkan media komunikasi yang ada seperti WhatsApp Group (WAG), telegram atau kontak melalui media Telefon. Petugas kesehatan dapat mengontrol dan mengingatkan lansia tentang waktu control tekanan darah, pengobatan dan diet dirumah atau dapat juga mendorong keluarga lansia untuk dapat mengontrol orang tua mereka di rumah.

\section{UCAPAN TERIMAKASIH}

Peneliti mengucapkan terima kasih kepada Kepala Dinas Kesehatan Kota Palu, Kepala Puskesmas Bulili, Pengelola Program Lansia dan PTM dan lansia di Posbindu Puskesmas Bulili.

\section{DAFTAR PUSTAKA}

Adventus, Jaya, I. M. M., \& Mahendra, D. (2016). Buku Ajar Promosi Kesehatan. Pusdik SDM Kesehatan, $1,6-8$.

Anugrah, Y., Saibi, Y., Betha, O. S., \& Anwar, V. A. (2020). Kepatuhan Minum Obat Pasien Hipertensi di Rumah Sakit Umum Daerah (Rsud) Tangerang Selatan. SCIENTIA: Jurnal Farmasi dan Kesehatan, 10(2), 224. https://doi.org/10.36434/scientia.v10i 2.322 .

Badrul Huda, S. K. dan D. H. (2020). Analisis Ketersediaan Obat Antihipertensi Dan Pengaruhnya Terhadap Pengobatan Pasien Hipertensi di Puskesmas Kota Bandar Lampung. Syntax Literate: Jurnal Ilmiah Indonesia, 5(6), 34-49.

Candrayani Dwi Siswanti DS. (2020). Hubungan tingkat pengetahuan tentang hipertensi dengan kepatuhan minum obat pada penderita hipertensi. Universitas Muhammadiyah Surakarta.
Dike, F. M., \& O., E. I. (2017). FaktorFaktor yang Berhubungan dengan Tekanan Darah pada Masa Pandemi Covid-19. Journal of Health Science Research, 2(1), 1-9. http://www.informaticsjournals.com/i ndex.php/jhsr/article/view/8530/1361 8.

Dilianty, O. M., Sianturi, S. R., \& Marlina, P. W. N. (2019). Peningkatan Kepatuhan Berobat Melalui Edukasi Bagi Penderita Hipertensi Dd Kabupaten Flores Timur. Jurnal Ilmiah Kesehatan Keperawatan, 15(2), 55-63. https://doi.org/10.26753/jikk.v15i2.3 05.

Direktorat Pengendalian, \& Penyakit Tidak Menular, Direktorat Jenderal PP \& PL, D. K. R. (2006). Pedoman Teknis Penemuan Dan tatalaksana Penyakit Hipertensi.

Fauzia, R. N. A. (2018). Hubungan Health Literacy dengan kepatuhan minum obat anggota komunitas bipolar care indonesia. Fakultas Psikologi dan Kesehatan Universitas Islam Sunan Ampel Surabaya, 121.

Friskilla Simanjuntak. (2020). FaktorFaktor Yang Berhubungan Dengan Kepatuhan Berobat Pasien TB Paru Di Puskesmas Glugur Darat Kecamatan Medan Timur Tahun 2019. Fakultas Kesehatan Masyarakat Universitas Sumatera Utara.

Hanum, S., Puetri, N. R., Marlinda, M., \& Yasir, Y. (2019). Hubungan Antara Pengetahuan, Motivasi, Dan Dukungan Keluarga Dengan Kepatuhan Minum Obat Pada Penderita Hipertensi Di Puskesmas Peukan Bada Kabupaten Aceh Besar. Jurnal Kesehatan Terpadu (Integrated Health Journal), 10(1), 30-35. https://doi.org/10.32695/jkt.v10i1.28.

Hardani, Nur Hikmatul Auliya, Helmina Andriani, Roushandy Asri Fardani, Jumari Ustiawaty, Dhika Juliana 
Sukmana, R. R. I. (2020). Buku Metode Penelitian Kualitatif \& Kuantitatif (Nomor April).

Ihwatun, S., Ginandjar, P., Saraswati, L. D., \& Udiyono, A. (2020). Faktor-Faktor Yang Berhubungan Dengan Kepatuhan Pengobatan Pada Penderita Hipertensi Di Wilayah Kerja Puskesmas Pudakpayung, Kota Semarang. Jurnal Kesehatan Masyarakat (e-Journal), 8(3), 352359.

Imas Masturoh, N. A. T. (2018). Metodologi Penelitian Kesehatan. In Kementerian Kesehatan Republik Indonesia.

Imelda Icca Napitupulu. (2019). Gambaran Tingkat Kecemasan Berdasarkan Karakteristik Pada Lansia Yang Menderita Hipertensi Di Puskesmas Pancur Batu Tahun 2019. Keperawatan Poltekkes Kemenkes Medan.

Indri Dwi Rahasasti, \& Neni Laeliyah. (2020). Pengaruh Edukasi Farmasi Terhadap Pengetahuan dan Kepatuhan Minum Obat Pada Pasien Hipertensi Peserta Prolanis Di Puskesmas Kaliwedi Kabupaten Cirebon. Syntax Idea, 2(7), 225-231.

Jamaludin. (2018). Pengaruh Dukungan Keluarga dan Dukungan Petugas Kesehatan terhadap Kepatuhan Berobat pada Penderita Lansia dengan Hipertensi di Puskesmas Gribig Kudus. Jurnal profesi keperawatan. Kudus.2018. Jurnal Profesi Keperawatan Akademi Keperawatan Krida Husada Kudus, 5(1), 69-84.

Kemenkes RI. (2020). Petunjuk Teknis Pelayanan Puskesmas Pada Masa Pandemi Covid-19. In Kemenkes RI. https://covid19.kemkes.go.id/protokol -covid-19/petunjuk-teknis-pelayananpuskesmas-pada-masa-pandemicovid-19/\#.X6z9Be77TIU.
Kementerian Pemberdayaan Perempuan dan Perlindungan Anak Republik Indonesia. (2020). Panduan Perlindungan Lanjut Usia Berperspektif Gender Pada Masa Covid-19. In Https://Covid19.Go.Id/. https://covid19.go.id/storage/app/media/Pro tokol/PANDUAN COVID LANSIA PEREMPUAN ttd paraf.pdf.

Kevin B. Katuuk, M. E., \& Bataha, Y. B. (2019). Hubungan Self-Efficacy Dengan Kepatuhan Minum Obat Hipertensi di Puskesmas Ranotana Weru Kota Manado. Jurnal Keperawatan, 7(1), 1-9.

Kurnia, A. (2016). Analisis Faktor-Faktor Yang Memengaruhi Kepatuhan Penderita Hipertensi Dalam Perawatan Hipertensi Di Wilayah Kerja Puskesmas Cibeureum Kota Tasikmalaya. Jurnal Kesehatan Bakti Tunas Husada: Jurnal Ilmu-ilmu Keperawatan, Analis Kesehatan dan Farmasi, 16(1), 143. https://doi.org/10.36465/jkbth.v16i1. 177.

Laporan Nasional Riskesdas. (2018). Laporan Nasional Reskesdas 2018.

Liberty, I. A., Pariyana, P., Roflin, E., \& Waris, L. (2018). Determinan Kepatuhan Berobat Pasien Hipertensi Pada Fasilitas Kesehatan Tingkat I. Jurnal Penelitian dan Pengembangan Pelayanan Kesehatan, 1(1), 58-65. https://doi.org/10.22435/jpppk.v1i1.4 28

Listiana, D., Effendi, S., \& Saputra, Y. E. (2020). Faktor-Faktor Yang Berhubungan Dengan Kepatuhan Penderita Hipertensi Dalam Menjalani Pengobatan Di Puskesmas Karang Dapo Kabupaten Muratara. Journal of Nursing and Public Health, 8(1), 11-22. https://doi.org/10.37676/jnph.v8i1.10 05

Masriadi, Arifin, M. S., \& Azis, R. (2019). Effect of supervisory drink drugs (SDG) on decreasing blood pressure 
reduction in hypertension patients, Indonesia. Indian Journal of Forensic Medicine and Toxicology, 13 (3), pp. 366-371.

https://doi.org/10.37506/ijfmt.v13i3.4 03.

Masriadi, Azis, R., Sumantri, E., \& Mallongi, A. (2018). Effectiveness of non pharmacologic therapy through surveillance approach to blood pressure degradation in primary hypertension patients, Indonesia. Indian Journal of Public Health Research and Development, 9 (2), pp. 249-255.

https://doi.org/10.5958/09765506.2018.00292.9.

Mega Intan Cahyawaty. (2017). Hubungan Dukungan Keluarga Dengan Perilaku Lansia Dalam Pengendalian Hipertensi Di Wilayah Puskesmas Pilangkenceng Kabupaten Madiun. Sekolah Tinggi Ilmu Kesehatan Bhakti Husada Mulia Madiun, 1-27. https://ci.nii.ac.jp/naid/40021243259/

Naelal, S. ;, Rohita, T., Milah, \& Samiatul, A. (2020). Hubungan Dukunga Keluarga Dengan Kepatuhan Minum Obat Pada Penderita Hipertensi di Wilayah Kerja Puskesmas Pamarican Kabupaten Ciamis Tahun 2020.

Nopitasari, B. L., Adikusuma, W., Qiyaam, N., \& Fatmala, A. (2019). Pengaruh Kepatuhan dan Ketepatan Waktu Minum Obat Terhadap Tekanan Darah Pasien Hipertensi Primer. Jurnal Ulul Albab LPPM UMMAT, 23(2).

Nuvri Nur Ardiyantika. (2019). FaktorFaktor yang Berhubungan Dengan Kepatuhan Berobat Penderita Hipertensi di Posbindu PTM Desa Sidorejo Kecamatan Geneng Kabupaten Ngawi. Sekolah Tinggi Ilmu Kesehatan Bhakti Husada Mulia Madiun, 11(1), 1-14. http://scioteca.caf.com/bitstream/han dle/123456789/1091/RED2017-Eng- 8ene.pdf? sequence $=12 \&$ is Allowed $=y \% 0 \mathrm{~A}$ http://dx.doi.org/10.1016/j.regsciurbe co.2008.06.005\%0Ahttps://www.rese archgate.net/publication/305320484 SISTEM_PEMBETUNGAN_TERP USAT_STRATEGI_MELESTARI

Oktaviani, E., Zunnita, O., \& Handayani, M. (2020). Efek Edukasi Melalui Brosur Terhadap Kontrol Tekanan Darah Dan Kepatuhan Pasien Hipertensi. Fitofarmaka: Jurnal Ilmiah Farmasi, 10(1), 65-75. https://doi.org/10.33751/jf.v10i1.206 0

Perhimpunan Dokter Spesialis Kardiovaskular Indonesia. (2015). Pedoman Tatalaksana Hipertensi Pada Penyakit Kardiovaskular.

Pratiwi, R. I. (2017). Analisis FaktorFaktor yang Mempengaruhi Kepatuhan Pasien Hipertensi Dalam Penggunaan Obat di RSUD Kardinah. Seminar IPTEK Terapan, 2(3), 15-17.

Pratiwi, W., Harfiani, E., \& Hadiwiardjo, Y. H. (2020). Faktor-Faktor Yang Berhubungan Dengan Kepatuhan Dalam Menjalani Pengobatan Pada Penderita Hipertensi Di Klinik Pratama GKI Jabar Jakarta Pusat. Seminar Nasional Riset Kedokteran, 27-40.

https://conference.upnvj.ac.id/index.p $\mathrm{hp} /$ sensorik/article/view/430

Profil Dinas Kesehatan Provinsi Sulteng. (2019). Profil Kesehatan Tahun 2019. In Dinas Kesehatan Sulawesi Tengah.

Purnawan, I. N. (2019). Kepatuhan Berobat Penderita Hipertensi Di Wilayah Kerja Puskesmas Payangan Kabupaten Gianyar. Jurnal Kesehatan Terpadu, 3(1), 15-21. https://doi.org/10.36002/jkt.v3i1.709

Puspita, E., Oktaviarini, E., Dyah, Y., Santik, P., Ilmu, A., Masyarakat, K., Negeri, U., Epidemiologi, M., Pasca, S., Universitas, S., Semarang, D., Ilmu, J., Masyarakat, K., Negeri, U., 
\& Pengobatan, K. (2017). The Role Of Family And Health Officers In Compliance Treatment Of Hypertension Patients. J. Kesehat. Masy. Indonesia, 12(2), 25-32.

Rahman, A. F. (2021). Gambaran Kondisi Lansia Penderita Covid 19 dengan Penyakit Diabetes Melitus dan Hipertensi: Literature Review. Universitas Muhammadiyah Surakarta, 1-19. http://eprints.ums.ac.id/89249/

Sagita, S., Budiman, B., \& Nurjanah, N. (2019). Faktor-faktor yang berhubungan dengan penyakit hipertensi di pengungsian wilayah kerja Puskesmas Kamonji. Jurnal Kolaboratif Sains, 1(1), 204-2016.

Setyoningsih, H., \& Zaini, F. (2020). Analisis Kepatuhan Terhadap Efek Terapi Pada Pasien Hipertensi di Poli Rawat Jalan RSUD dr.R.Soetrasno Rembang. Jurnal keperawatan dan Kesehatan Masyarakat STIKES Cendekia Utama Kudus, 9(2), 156168.

Tim Kerja Kementerian Dalam Negeri. (2020). Pedoman Umum Menghadapi Pandemi Covid-19 Bagi Pemerintah Daerah: Pencegahan, Pengendalian, Diagnosis dan Manajemen. Journal of Chemical Information and Modeling, 53(9), 1689-1699. https://doi.org/10.1017/CBO9781107 415324.004

Tri Retno Widianingrum. (2017). Hubungan Pengetahuan dan Motivasi Dengan Kepatuhan Minum Obat Anti Tuberkulosis Pada Pasien TB di Wilayah Kerja Puskesmas Perak Timur Surabaya. IR-Perpustakaan Universitas Airlangga.

Wasistiono Indrayani, Sadu, Etin, Pitono, \& Andi. (2020). Panduan Pelayanan Kesehatan Lanjut Usia Pada Era Pandemi Covid-19. In Kementerian Kesehatan Republik Indonesia (Nomor March).
Widyastuti, Y., \& Nurul Istiqomah. (2021). Kontrol Hipertensi di Rumah Dengan Touch Therapi Kaki dan Akupresure Di Masa Pandemi COVID19. Institut Teknologi Sains Dan Kesehatan PKU Muhammadiyah Surakarta, 6.

Winny, G. I. P., Ramadhani Nasution, S. L., Suyono, T., \& Girsang, E. (2018). Analisis faktor-faktor yang mempengaruhi kepatuhan konsumsi obat pada pasien hipertensidi puskesmas sunggal medan tahun 2018. Scientia Journal, 8(2).

Yulia Susanti, Anita, D. Y. A. S. (2021). Perilaku CERDIK Penderita Hipertensi di Masa Pandemi Covid 19. Jurnal Keperawatan, 13, 61-76.

Yulike Mangendai, Rompas, S., Hamel, \& S., R. (2017). Faktor-faktor yang berhubungan dengan kepatuhan berobat pada pasien hipertensi. $e$ Journal Keperawatan (e-Kp), 5, 1-8.

Ziyana Walidah. (2017). Pengaruh Pemberian Edukasi Terhadap Pengetahuan Dan Sikap Pasien Hipertensi di Puskesmas Sutojayan Kabupaten Blitar. Central Library Of Maulana Malik Ibrahim States Islamic. 